\title{
STRATEGI PENGEMBANGAN AGRIBISNIS PADI MELALUI PEMBANGUNAN RICE ESTATE DI KABUPATEN KUBU RAYA
}

\author{
Budi Syahrizal*, Abdul Hamid A. Yusra**, Sutarman Gafur** \\ *Mahasiswa MMA Fakultas Pertanian Universitas Tanjungpura Pontianak \\ ** Staf Pengajar Fakultas Pertanian Universitas Tanjungpura Pontianak
}

\begin{abstract}
ABSTARCT
Budi Syahrizal "Rice Agribusiness Development Strategy Development Through Rice Estate in Kubu Raya District", under the guidance of Ir . A. Hamid A. Yusra, MS and Dr. Ir. H. Sutarman Gafur, M.Sc. The research aims to: 1. Knowing the real rice management by Kubu Raya District Government in increasing rice production. 2. Identifying factors external environment into opportunities and threats management of real rice and internal environmental factors are the strength and weaknesses of the management of real rice. 3. Formulate alternative strategies that can be implemented according to the manager of the rice area real environmental conditions. 4. Analyzing priority management strategies that can be implemented in accordance with the environmental conditions of real rice area .
\end{abstract}

Benefits of this research are : 1. As an input for the management of real rice in Kubu Raya District to be considered in carrying on their business in the face of environmental changes occur real rice. 2. This study is also expected to be material information for the various parties involved in the management of real rice to prepare measures that can improve the production and productivity of rice in order to self-sufficiency and food security in Indonesia, particularly the Kubu Raya District immediately reached. 3. As for the academics, hopefully this study can be material information, comparisons and references for further studies.

The research was conducted in the village of Kuala Foreman A B District Overseer Kuala Kubu Raya district of West Kalimantan Province and held for about 2 months.

Method used was a survey method and included in the descriptive study. The population in this study are all stakeholders involved in the system of rice agribusiness. The sampling technique used was purposive sampling, which determine directly or selecting respondents deliberately .

The results of this study are : SWOT analysis matrix shows the internal - external strategic factors obtained is : SO the value of 3,2748 , with a value of 3,0448 ST, WO and WT with a value of 2.5888 with a value of 2.3588 . Thus rice agribusiness development strategy through a in Kubu Raya District can use the SO strategy.

Keywords : Strategy, Sustainability, Rice, Rice Estate, SWOT.

\section{PENDAHULUAN}

\section{Latar Belakang}

Undang-undang (UU) No. 7 tahun 1996 tentang pangan mengamanatkan : (a) bahwa pangan merupakan kebutuhan dasar manusia yang pemenuhannya menjadi hak asasi setiap rakyat Indonesia dalam mewujudkan sumber daya manusia yang berkualitas untuk melaksanakan pembangunan nasional; (b) bahwa pangan yang aman, bermutu, bergizi, beragam, dan tersedia secara cukup merupakan prasyarat utama yang harus dipenuhi dalam upaya terselenggaranya suatu sistem pangan yang memberikan perlindungan bagi 
kepentingan kesehatan serta makin berperan dalam meningkatkan kemakmuran dan kesejahteraan rakyat.

Beras adalah produk utama dari tanaman padi yang merupakan makanan pokok dari penduduk Asia termasuk Indonesia. Peranan beras bagi bangsa Indonesia saat ini tidak hanya sekedar komoditas pangan saja tetapi juga memiliki nilai sensitivitas politik, ekonomi dan kerawanan sosial yang sangat tinggi (Suryana, 2002). Oleh karena itu, campur tangan pemerintah Indonesia sangatlah besar dalam upaya peningkatan produksi dan stabilitas harga beras. Kecukupan pangan (terutama beras) dengan harga yang terjangkau telah menjadi tujuan utama kebijakan perberasan di Indonesia. Demikian tergantungnya penduduk Indonesia pada beras maka sedikit saja terjadi gangguan pada produksi beras misalkan gagal panen maka pasokan menjadi terganggu yang berdampak pada harga jual meningkat (Agus Andoko, 2002:11).

Indonesia merupakan salah satu negara produsen beras terbesar di dunia, hal ini sejalan dengan produksi padi nasonal yang mencapai 34 juta ton per tahun. Namun tingginya tingkat konsumsi beras nasional tidak diimbangi dengan peningkatan produksi yang memadai membuat Indonesia menjadi salah satu net importer beras terbesar di dunia sejak tahun 1998. Kariyasa (2003) mencatat bahwa Indonesia mengimpor hampir 50 persen dari stok total beras dunia atau rata-rata sebesar 1,5 juta ton per tahun selama periode tahun 1990-1999. Data produksi produksi padi nasional sejak tahun $1999-2011$ dapat disajikan pada tabel 1 . berikut:

Tabel 1. Luas Panen, Produktivitas dan Produksi Padi dari Tahun 1999-2011

\begin{tabular}{cccccc}
\hline Tahun & $\begin{array}{c}\text { Luas Panen } \\
\text { (Ha) }\end{array}$ & $\begin{array}{c}\text { Produktivitas } \\
\text { (Ton/Ha) }\end{array}$ & $\begin{array}{c}\text { Produksi Padi } \\
\text { (Ton) }\end{array}$ & $\begin{array}{c}\text { Produksi Beras } \\
\text { (Ton) }\end{array}$ & $\begin{array}{c}\text { Pertumbuhan } \\
\text { Produksi Beras (\%) }\end{array}$ \\
\hline 1998 & 11.730 .325 & 4,197 & 50.866 .387 & 32.045 .824 & 3,02 \\
1999 & 11.963 .204 & 4,252 & 49.236 .692 & 31.019 .116 & $-3,20$ \\
2000 & 11.793 .475 & 4,401 & 51.898 .852 & 32.696 .277 & 5,40 \\
2001 & 11.499 .997 & 4,388 & 50.460 .762 & 31.790 .280 & $-2,80$ \\
2002 & 11.521 .166 & 4,469 & 51.489 .694 & 32.438 .507 & 2,04 \\
2003 & 11.488 .034 & 4,538 & 52.137 .604 & 32.846 .691 & 1,26 \\
2004 & 11.922 .974 & 4,536 & 54.088 .468 & 34.075 .735 & 3,74 \\
2005 & 11.839 .060 & 4,574 & 54.151 .097 & 34.075 .735 & 0,43 \\
2006 & 11.786 .430 & 4,620 & 54.454 .937 & 34.306 .610 & 0,24 \\
2007 & 12.147 .637 & 4,705 & 57.157 .435 & 35.940 .591 & 4,76 \\
2008 & 12.327 .425 & 4,894 & 60.325 .925 & 38.005 .333 & 5,74 \\
2009 & 12.883 .576 & 4,999 & 64.398 .890 & 40.571 .301 & 6,75 \\
2010 & 13.253 .450 & 5,015 & 66.469 .394 & 41.875 .718 & 3,22 \\
2011 & 13.203 .643 & 4,980 & 65.756 .904 & 41.426 .850 & $-1,07$ \\
\hline Sumber & : BPS (2012), diolah & & & \\
\hline
\end{tabular}

Keterangan : Konversi gabah ke beras adalah $63,2 \%$ (BPS)

Data Tabel 1. menunjukkan bahwa dalam kurun waktu empat belas tahun terakhir telah terjadi peningkatan produksi padi, meskipun cenderung fluktuatif. Tingkat pertumbuhan produksi beras rata-rata sekitar 2,11 persen per tahun atau setara dengan satu juta ton 
beras. Penurunan produksi yang terjadi pada tahun 1999 sebesar 3,20 persen disebabkan bencana El-Nino tahun 1998 yang mempengaruhi jumlah panen tahun berikutnya. Penurunan produksi juga disebabkan oleh penurunan luas lahan yang dikonversi, penggunaan input yang kurang berkualitas, degradasi kualitas lahan, penurunan rendemen beras dan teknologi pasca panen yang kurang tepat. Penurunan produksi padi menjadi determinan yang penting dalam produksi beras di Indonesia. Hal ini disebabkan karena setiap penurunan rendemen beras sebesar 1 persen, berarti produksi beras berkurang 0,5 juta ton beras. Nilai ini penting karena Indonesia merupakan net importer beras dunia dengan jumlah penduduk yang besar.

Setelah tahun 2002, produksi padi terus meningkat secara positif meskipun pertumbuhannya sangat fluktuatif. Peningkatan produksi didorong dengan adanya peningkatan luas areal tanam dan peningkatan produktivitas. Pascakrisis ekonomi tahun 1998, produktivitas terus meningkat dengan pertumbuhan rata-rata 4,46 persen per tahun. Kenaikan yang cukup besar terjadi pada tahun 2007 yaitu 4,76 persen. Hal ini didorong oleh adanya kebijakan Peningkatan Produksi Beras Nasional (P2BN) pada awal tahun 2007. Selain itu, pertumbuhan produksi juga dipicu oleh adanya kebijakan harga, baik Harga Dasar ataupun Harga Pengadaan Pemerintah (procurement price) yang bertujuan untuk mengurangi kerugian produsen padi akibat tingginya biaya produksi.

Data cuplikan nasional tahun 2009 menunjukkan bahwa semua pulau di Indonesia memiliki potensi yang cukup besar dalam memproduksi padi, meskipun terdapat perbedaan jumlah luas lahan (Ha), produktivitas (ton/ha), dan produksi (ton). Berdasarkan data, pulau dengan produksi padi terbesar secara berturut-turut adalah : Pulau Jawa, Sumatera, Sulawesi, Kalimantan, Bali dan Nusa Tenggara, serta Maluku dan Papua (Tabel 2).

Tabel 2. Luas Panen, Produktivitas, dan Produksi Padi Nasional Tahun 2009

\begin{tabular}{clccc}
\hline No & Pulau & $\begin{array}{c}\text { Luas Panen } \\
\text { (Ha) }\end{array}$ & $\begin{array}{c}\text { Produktivitas } \\
\text { (Ton/Ha) }\end{array}$ & \multicolumn{1}{c}{$\begin{array}{c}\text { Produksi } \\
\text { (Ton) }\end{array}$} \\
\hline 1 & Jawa & 6.093 .60 & 5,72 & 34.880 .131 \\
2 & Sumatera & 3.330 .61 & 4,41 & 14.696 .457 \\
3 & Sulawesi & 1.399 .13 & 4,86 & 6.801 .668 \\
4 & Kalimantan & 1.269 .65 & 3,46 & 4.392 .112 \\
5 & Bali \& Nusa Tenggara & 718.78 & 4,67 & 3.356 .898 \\
6 & Maluku dan Papua & 71.785 & 3,78 & 271.624 \\
\hline \multicolumn{2}{r}{ Jumlah } & 12.883 .57 & 4,49 & 64.398 .890 \\
\hline
\end{tabular}

Sumber : BPS 2010 (diolah)

Tantangan utama sektor tanaman pangan adalah bagaimana upaya untuk memenuhi kebutuhan konsumsi beras nasional dari produksi dalam negeri. Konsumsi beras terus meningkat seiring dengan bertambahnya jumlah penduduk, sementara itu upaya diversifikasi pangan pokok (sumber karbohidrat) belum membuahkan hasil sebagaimana yang diharapkan. Dari sisi lain laju pertumbuhan produksi padi nasional menunjukkan gejala stagnan bahkan menurun. Pada era tahun 2000-an ini, pertumbuhan produksi beras meningkat dibawah $1 \%$ per tahun. Lebih rendah bila dibandingkan pada era 1990-an yang rata-rata meningkat $1,47 \%$ per tahun dan jauh lebih rendah dibandingkan dengan periode tahun 1980-an, dimana pertumbuhan produksi rata-rata mencapai $4,34 \%$ per tahun. 
Kondisi menurunnya produksi padi nasional berkaitan dengan dua faktor utama, pertama luas lahan budidaya padi sejak periode tahun 2000-an tidak mengalami penambahan meskipun ada perluasan lahan budidaya, artinya upaya perluasan lahan budidaya padi hanya sebanding dengan laju konversi lahan produktif untuk kepentingan nonpertanian. Irawan (2003) melaporkan bahwa selama 1978-1998 sekitar 1,07 juta ha lahan $(30,8 \%)$ telah terkonversi menjadi lahan nonpertanian. Selama periode yang sama, terdapat pembukaan sawah baru sekitar 0,91 juta ha. Faktor yang kedua upaya untuk meningkatkan produktivitas masih menghadapi berbagai kendala, baik teknis-agronomis maupun sosialekonomi-budaya. Produktivitas padi saat ini rata-rata 4,5 ton/hektar, masih jauh dibawah potensi hasil varietas padi unggul yang telah dilepas yang berkisar antara 6,0 - 9,0 ton/hektar. Varietas unggul yang paling banyak dibudidayakan petani adalah IR64 (introduksi dari IRRI) yang dilepas tahun 1986 dengan potensi hasil yang tidak terlalu tinggi, yakni hanya 6,0 ton/hektar (Lakitan, 2007).

Adanya dua permasalahan tersebut telah menumbuhkan gagasan bagi pemerintah Kabupaten Kubu Raya untuk membangun sentra produksi beras yang disebut dengan rice estate. Pembangunan kawasan rice estate telah dimulai tahun sejak tahun 2009 dan akan berlanjut hingga 2014. Dalam rangka mewujudkan visi pembangunan pertanian Kabupaten Kubu Raya maka pembangunan rice estate akan dikembangkan pada setiap kecamatan yang pengelolaannya manajemennya sementara ditangani langsung Dinas Pertanian dan Peternakan Kabupaten Kubu Raya selanjutnya akan diserahkan pada kelompok tani sebagai pelaku langsung dilapangan. Kendala yang dialami pengelola adalah produksi belum sesuai dengan harapan, sistem manajemen belum berjalan dengan baik karena pengelola belum dapat memfungsikan petugas (pengelola) dan petani dengan baik sehingga masih terdapat ketidaksesuaian antara struktur organisasi dengan pekerjaan yang dilakukan oleh petugas. Selain itu, terbatasnya kemampuan pengetahuan petani dalam mengadopsi paket teknologi rice estate karena kurang didukung dengan penyuluhan yang berkesinambungan.

Menghadapi situasi dan kondisi demikian maka untuk mengoptimalkan pengembangan kawasan rice estate di Kabupaten Kubu Raya Pemerintah Daerah harus lebih proaktif dalam penentuan dan pemilihan strategi guna mendukung peningkatan produksi. Berdasarkan uraian diatas, maka penelitian ini bertujuan :

Untuk mengetahui pengelolaan rice estate oleh pemerintah Kabupaten Kubu Raya dalam meningkatkan produksi beras. 2) Mengidentifikasi faktor-faktor lingkungan eksternal yang menjadi peluang dan ancaman pengelola rice estate serta faktor-faktor lingkungan internal yang menjadi kekuatan dan kelemahan pengelola rice estate. 3) Merumuskan alternatif strategi yang dapat dijalankan pihak pengelola sesuai dengan kondisi lingkungan kawasan rice estate. 4) Menganalisis prioritas strategi yang dapat dijalankan pengelola sesuai dengan kondisi lingkungan kawasan rice estate.

\section{Metode Penelitian}

Jenis penelitian ini adalah deskriptif dengan metode survai. Menurut Whitney (1960) dalam Nazir (2005) metode deskriptif adalah pencarian fakta dengan interpretasi yang tepat. Penelitian deskriptif mempelajari masalah-masalah serta tata cara yang berlaku dalam masyarakat serta situasi tertentu termasuk tentang hubungan, kegiatan, sikap, pandangan serta proses yang sedang berlangsung dan pengaruh dari suatu fenomena.

Metode survei adalah penyelidikan yang diadakan untuk memperoleh fakta-fakta dari gejala-gejala yang ada dan mencari keterangan-keterangan secara faktual. Dalam metode survey juga dilakukan evaluasi serta perbandingan terhadap hal-hal yang telah dikerjakan orang dalam dalam menangani situasi atau masalah yang serupa dan hasilnya dapat 
digunakan dalam pembuatan rencana dan pengambilan keputusan dimasa mendatang (Nazir, 2005). Penelitian ini dilaksanakan di Desa Kuala Mandor A Kecamatan Kuala Mandor B Kabupaten Kubu Raya Propinsi Kalimantan Barat dan dilaksanakan selama kurang lebih 2 (dua) bulan untuk proses identifkasi data primer dan data sekunder, sedangkan proses penyusunan laporan penelitian sampai selesai memerlukan waktu 4 (bulan). Lokasi penelitian dipilih secara sengaja (purposive) dengan pertimbangan bahwa Kabupaten Kubu Raya merupakan salah satu diantara kabupaten yang melaksanakan program Rice Estate, letak geografis Kabupaten Kubu Raya cukup strategis diantara kabupaten lain dan termasuk salah satu kawasan sentra produksi padi di Kalimantan Barat.

\section{Populasi dan Sampel Penelitian}

a. Penentuan responden dapat dikelompokkan menjadi 2 (dua) bagian yaitu dari para ahli (pakar) atau pengambil keputusan yang akan memberikan masukan dalam proses identifikasi dan penentuan faktor-faktor internal dan eksternal sampai pada tahapan menentukan alternatif atau pilihan formulasi strategi. Penetuan para ahli/pakar ini berdasarkan pertimbangan tingkat penguasaan, pengalaman dan kompetensi terhadap objek yang diteliti dalam penelitian ini Jumlah responden dari kelompok pakar adalah 6 orang yang terdiri dari unsur pemerintah selaku pengambil kebijakan terdiri dari Kepala Dinas (Kadis) Pertanian dan Peternakan Kabupaten Kubu Raya, Kepala Badan Ketahanan Pangan Kabupaten Kubu Raya, Kadis Perindustrian dan Perdagangan Kabupaten Kubu Raya, Kadis Koperasi dan UKM Kabupaten Kubu Raya, Kepala Badan Urusan Logistik (Bulog), dan lembaga dari perguruan tinggi.

b. Kelompok kedua yaitu responden dari pelaksanan dan stakeholder yang berhubungan langsung dalam pengelolaan rice estate (18 responden) yaitu terdiri dari pelaksana/manager rice estate 1 responden, perusahaan PT. Sang Hyang Sri (SHS) Perwakilan Kalbar 1 responden, petani (masyarakat) 10 responden, aparat pembina 2 responden, pedagang dan pengusaha alat pertanian 4 responden. Perincian responden dapat dilihat pada tabel

\section{Teknik Pengumpulan Data}

a. Data yang digunakan terdiri dari data primer dan data sekunder yang diperoleh dari berbagai sumber. Data primer diperoleh dari observasi berupa penyebaran kuesioner, wawancara dengan responden, sementara data sekunder diperoleh melalui studi pustaka dengan mengkaji referensi terpilih dan mengumpulkan data dan informasi dari instansi yang terkait dengan bidang kajian penelitian.

b. Data primer terdiri dari tingkat keterlibatan stakeholders dalam pengelolaan agribisnis, faktor internal dan eksternal, strategi pengelolaan yang diharapkan, pandangan terhadap kebijakan yang berhubungan dengan pengembangan agribisnis; usaha agribisnis saat ini serta sarana dan prasarana pendukung. Data sekunder terdiri dari data penduduk dan tenaga kerja, sarana dan prasarana, pola dasar pembangunan daerah, potensi daerah dan komoditas agribisnis, peraturan dan kebijakan pemerintah, pendapatan sektor pertanian dan sumbangan terhadap PDRB.

\section{Teknik Pengambilan, Pengolahan dan Analisis Data}

Pengambilan data menggunakan metode Delphi. Menurut Marimin (2004) metode Delphi adalah metode pengambilan keputusan berbasis indeks kinerja yang menyelaraskan proses komunikasi suatu grup sehingga dicapai suatu proses yang efektif dalam mendapatkan solusi masalah yang kompleks. Data dan informasi yang diperoleh diolah dan dianalisis secara kualitatif dan kuantitatif. Analisis kuantitatif dilakukan untuk 
menganalisis lingkungan internal dan eksternal termasuk situasi persaingan yang diwujudkan dalam matriks External Factor Evaluation (EFE) dan matriks Internal Factor Evaluation (IFE). Selanjutnya analisis kualitatif menggunakan matriks SWOT .

\section{Hasil Dan Pembahasan}

\section{a. Analisis Faktor - Faktor Strategis Pengembangan Agrbisnis Padi Melalui Pembangunan Rice Estate di Kabupaten Kubu Raya.}

Untuk menganalisis faktor-faktor strategis yang mempengaruhi dan menentukan keberhasilan pengembangan agribisnis beras melalu pembangunan rice estate di Kabupaten Kubu Raya dilakukan dengan analisis IFE, analisis EFE dan analisis SWOT. Analisis ini dilakukan melalui pengamatan faktor - faktor lingkungan, baik internal ( Kekuatan dan kelemahan ) maupun faktor eksternal ( peluang dan ancaman ) yang dimiliki oleh Pemerintah Kabupaten Kubu Raya selaku pengambil kebijakan. Penelitian ini untuk mengetahui pengelolaan kawasan rice estate dan untuk mengetahui factor lingkungan internal dan eksternal yang dibatasi pada beberapa Satuan Kerja Perangkat Daerah (SKPD) yang menangani

langsung dalam upaya pengembangan agribisnis perberasan di Kabupaten Kubu Raya dan selaku pengambil kebijakan terdiri dari Kepala Dinas (Kadis) Pertanian dan Peternakan Kabupaten Kubu Raya, Kepala Badan Ketahanan Pangan Kabupaten Kubu Raya, Kadis Perindustrian dan Perdagangan Kabupaten Kubu Raya, Kadis Koperasi dan UKM Kabupaten Kubu Raya, Kepala Badan Urusan Logistik (Bulog), dan lembaga dari Perguruan Tinggi.

b. Faktor Internal ( Kekuatan ), antara lain :

\section{Kebijakan Pemerintah Dalam Mendukung Peningkatan Produksi Padi.}

Sebagai bentuk keseriusan dan perhatian khusus Pemerintah Daerah Kabupaten terhadap kebijakan pembangunan pertanian, maka Pemerintah Daerah Kubu Raya memberikan dukungan/mengalokasikan dana secara khusus dalam bentuk kegiatan yang terkait dengan program ini. Program yang dimaksud antara lain :

- Pembangunan pedesaan dengan memperioritaskan pembangunan pertanian salah satu contohnya pencetakan sawah baru yang dijadikan kawasan rice estate seluas 100 ha di Kecamatan Kuala Mandor B yang sudah dimulai sejak tahun 2009, kawasan yang dibangun merupakan lahan masyarakat yang belum tergarap sama sekali dan di sekitarnya memiliki potensi untuk dikembangkan yang luasannya berkisar \pm 200 ha sebagai pilot project.

- Meningkatkan ekonomi kerakyatan dengan membuka peluang pasar yang permanen melalui pembelian beras oleh PNS.

- Memberikan dukungan peningkatan produksi, produktifitas dan kualitas secara komprehensip dan terkonsentrasi, mulai dari sistem budidaya, panen dan pasca panen sampai pemasaran.

- Memfasilitasi pengembangan pola kemitraan dan keterpaduan atau integrasi usaha pertanian dalam arti luas.

- Pembangunan sarana dan prasarana / infrastruktur pertanian seperti: jalan usaha tani/jalan produksi, embung, saluran irigasi, pintu air, tanggul, pengadaan alat mesin pertanian, balai penyuluhan pertanian (kelembagaan pertanian), dll. 
Dukungan dan kebijakan pemerintah ini diharapkan akan menjadi stimulan bagi petani dalam pengembangan usaha pertaniannya guna peningkatan produksi padi. Selanjutnya jika dukungan pemerintah yang berbasis pro rakyat ini ditambah strategi produksi pangan yang besar dan modern, maka ketersediaan pangan dalam negeri akan terjamin ketersediaannya.

\section{Kinerja Pelayanan Aparat Terhadap Masyarakat Tani.}

Meningkatkan serta memberdayakan masyarakat tani perlu ditunjangi oleh peningkatan kapasitas atau keterampilan dalam mengolah tanaman. Pengetahuan dan keterampilan petugas dalam memberikan informasi terhadap petani sangat diperlukan guna peningkatan pelayanan terutama petugas pertanian lapangan guna memberikan bimbingan dan penyediaan stimulan untuk menggerakan peran serta petani dalam peningkatan ketrampilan. Program penyuluhan pertanian yang diutamakan adalah pengembangan lumbung pangan, penanganan daerah rawan pangan, pengembangan cadangan pangan daerah, pengembangan intensfikasi tanamann pangan. Muara dari hal ini mampu merubah sikap yang diharapkan bisa menunjang keberhasilan petani dalam menghadapi segala permasalahan dalam mengembangkan usahanya.

Lembaga Pembina selaku pelayan masyarakat yang terkait langsung maupun tidak langsung dalam memberikan pembinaan cukup besar peranannya dalam menentukan keberhasilan pengembangan agribisnis padi dan keberadaanya dharapkan dapat menjadi fasilitator bagi pelaku usaha padi baik yang bergerak dalam budidaya, penangan pasca panen,pemasaran hasil dan manajeman usaha. Lembaga ini mempunyai peran dalam menentukan kebijakan yang akan diterapkan di lapangan.

\section{Memiliki Unit Penggilingan Padi}

Untuk memaksimalkan usaha agribisnis pertanian diupayakan setiap Gapoktan memiliki usaha penggilingan padi untuk melayani dan menampung hasil panen petani. Data dari Dinas Pertanian dan Peternakann Kabupaten Kubu Raya jumlah penggilingan padi sebanyak 274 unit yang tersebar dibeberpa kecamatan data terlampir Demikian juga pada kawasan rice estate yang sudah dibangun sudah difasilitasi oleh pemerintah sarana penggilingan padi. Untuk memaksimalkan upaya tersebut Pemerintah Kabupaten Kubu Raya melakukan sosialisasi dan advokasi sistim mutu beras kepada penggilingan, perbaikan konfigurasi dilakukan dengan menata kembali mesin-mesin yang sudah ada atau penambahan mesin/alat yang sederhana sehingga kinerjanya optimal, Perbaikan konfigurasi difokuskan kepada penggilingan padi kecil (PPK) dan kegiatan yang diperlukan adalah memberikan penyuluhan kepada para pengusaha penggilingan padi agar memperbaiki konfiguasi mesinnya.

Dalam memaksimalkan hal tersebut diperlukan perbaikan proses kerja untuk memperbaiki mutu beras, penggilingan padi kecil hanya menghasilkan beras pecah kulit, selanjutnya beras pecah kulit diolah di penggilingan padi besar menjadi beras giling dengan proses kerja seperti tersebut, maka mutu beras yang dihasilkan akan menjadi lebih baik. Dari informasi Dinas Pertanian dan Peternakan Kabupaten Kubu Raya sebagian besar alat yang digunakan penggilingan padi sudah tua dengan teknologi yang sederhana serta pemeliharaan yang kurang intensif, untuk itu diperlukan upaya perbaikan teknologi yaitu melalui penggunaan alat-alat yang mendukung peningkatan mutu beras yang lain. 
Tabel 3. Data Penyebaran Alat Mesin Pertanian

\begin{tabular}{clcccccc}
\hline \multirow{2}{*}{ NO } & \multirow{2}{*}{ KECAMATAN } & \multicolumn{3}{c}{ Ketersediaan Alat Mesin } & \multicolumn{3}{c}{ Kekurangan Alat Mesin } \\
& & Perontok & RMU & Dryer & Perontok & RMU & Dryer \\
\hline 1 & Sungai Raya & 23 & 39 & 5 & 289 & 34 & 88 \\
2 & Rasau Jaya & 42 & 25 & 19 & 78 & - & 5 \\
3 & Sungai Ambawang & 40 & 47 & 5 & 76 & - & 17 \\
4 & Kuala Mandor B & 4 & 41 & 1 & 43 & - & 24 \\
5 & Terentang & 21 & 15 & 5 & 132 & 15 & 34 \\
6 & Kubu & 9 & 41 & 5 & 308 & 37 & 87 \\
7 & Batu Ampar & 13 & 31 & 5 & 398 & 47 & 110 \\
8 & Teluk Pakedai & 51 & 16 & 3 & 95 & 11 & 25 \\
9 & Sungai Kakap & 62 & 19 & 6 & 523 & 62 & 150 \\
\hline \multicolumn{1}{r}{ Jumlah } & 265 & 274 & 54 & 1942 & 172 & 540 \\
\hline Sumber Distannak KKR tahun 2012 & & & & & &
\end{tabular}

\section{Adanya Merek Dagang.}

Dalam upaya persaingan sehat dalam pemasaran hasil pertanian Pemerintah Kabupaten Kubu Raya melalu Dinas Pertanian dan Peternakan Kabupaten Kubu Raya bersama instansi terkait melakukan pembinaan terhadap Kelompok Tani / Gabungan Kelompok Tani. Untuk menampung hasil panen baik anggota kelompok maupun petani sekitar kelompok dengan harga sesuai mekanisme pasar (standar) dan di jual dengan membuat merek dagang sendiri, sesuai dengan ciri khas lokasi masing-masing sehingga setiap Gapoktan akan mengeluarkan produk berasnya dengan merek dagang sendiri. Dengan adanya merek dagang ini diharapkan harga beras ditingkat petani akan meningkat dan gairah petani untuk bertanam padi semakin bertambah. Adapun merek dagang yang sudah beredar di pasaran antara lain : anggrek macan dari Kubu Raya, Langsat Mas dari Desa Kalimas Kecamatan Sungai Kakap dan Mekar Wangi dari Desa Pal 9 Kecamatan Sungai Kakap.

\section{Kemasan Beras Sesuai Dengan Keinginan Konsumen.}

Untuk mengembangkan usaha, di bidang pertanian, Pemerintah Daerah Kubu Raya berupaya memberikan kemudahan bagi petani /Kelompok tani dalam hal memasarkan produk hasil panennya terutama beras dengan menyediakan program bantuan kemasan karung beras sesuai keinginan konsumen. Konsekuensi dari tugas dan tanggung jawab dalam mengembangkan pertanian di Kabupaten Kubu Raya, dicoba dengan memberikan bantuan ke beberapa penggilingan padi kemasan karung beras dengan beberapa ukuran sesuai keinginan konsumen diantaranya kemasan $5 \mathrm{~kg}$, kemasan $10 \mathrm{~kg}$ dan kemasan 20 $\mathrm{kg}$. Hal ini diharapkan agar kelompok tani/penggilingan padi yang ada dapat berkembang dengan adanya stimulan dari Pemerintah Kabupaten Kubu Raya. 


\section{c. Faktor Faktor Internal (Kelemahan ).}

\section{Prasarana dan Sarana Belum Maksimal}

Peningkatan produksi pertanian tidak terlepas dari kemudahan dan ketersediaan sarana dan prasarana pendukung lahan pertanian. Penyediaan sarana dan prasarana penunjang pertanian merupakan syarat mutlak yang harus dimiliki untuk dapat meningkatkan produksi pertanian baik produksi bahan mentah maupun bahan olahan. Pada umumnya penyediaan sarana produksi pertanian seperti pupuk dan pestisida sudah cukup ketersediaannya namun sarana /fasilitas jalan menuju lokasi dan sarana penunjang lainnya belum makasimal karena keterbatasan anggaran yang dialokasikan untuk pembangunan sarana dan prasarana penunjang lahan pertanian.

\section{Modal Kerja Belum Mencukupi.}

Ketersediaan modal dalam pengembangan usaha agribisnis tanaman padi sangat diperlukan guna meningkatan skala usaha tani yang besar dan berhasil guna, pengembangan modal bagi masyarakat khususnya petani pelaku usaha bisa diperoleh dari mitra usaha, koperasi/bank maupun dari pemerintah berupa kegiatan. Pada umumnya modal usaha petani di sekitar kawasan rice estate masih terbatas untuk pengembangan usaha agribisnis padi dalam skala luas, sehingga luas lahan dan biaya pemeliharaan tanaman disesuaikan dengan kemampuan petani dan akibatnya jumlah produksi dan kualitas yang dihasilkan menjadi belum optimal. Perluasan skala usaha harus berkorelasi positip dengan ketersediaan modal oleh karena itu keterbatasan modal menyebabkan petani merasa kesulitan

dalam mengembangkan usaha agribisnis padi di Kabupaten Kubu Raya umumnya dan di kawasan rice estate khususnya.

\section{Harga Pokok Produksi yang Masih Tinggi}

Salah satu aspek dalam meningkatkan produksi padi adalah terpenuhinya tanaman akan unsur hara yang dibutuhkan dan jika tanaman sudah terpenuhi unsur tersebut diharapkan terjadi peningkatan produksi dan mutu hasil, kelemahan yang sering terjadi selama ini pada usaha agribisnis adalah belum mampu menghasilkan produk yang sesuai dengan standar yang diinginkan konsumen. Hal tersebut disebabkan penyediaan akan sarana produksi oleh petani masih terbatas karena harga sarana produksi pertanian seperti pupuk dan benih masih cukup tinggi ditingkat pasaran dan masih belum terjangkau oleh petani pada umumnya, terutama petani yang baru merubah pola ke pertanian berskala luas seperti dikawasan rice estate. Hal ini dapat mengancam kelangsungan usaha petani dalam pengembangan usaha komoditas padi.

\section{Sistem Informasi Manajemen (SIM) Belum Diterapkan}

Pembangunan kawasan rice estate pada beberapa wilayah kecamatan di Kabupaten Kubu Raya (KKR) merupakan suatu upaya percepatan peningkatan produksi padi. Hasil utama rice estate adalah produksi beras yang sudah dikemas dalam berbagai ukuran. Tujuan pembangunan rice estate adalah membangun sentra pertanian yang modern dan berdaya saing berbasis perdesaan, sehingga dapat mewujudkan kabupaten ini sebagai pusat produksi beras di Provinsi Kalimantan Barat yang berbasis pada keterpaduan agribisnis beras yang berkelanjutan.

Kawasan rice estate yang sudah terealisasi sejak tahun 2009 adalah di Kecamatan Kuala Mandor B dengan luas mencapai $100 \mathrm{Ha}$ dan sudah panen dengan produktivitas 2,00 - 3,00 ton,/Ha. Kawasan rice estate yang ada di Desa Kuala Mandor A Kecamatan Kuala 
Mandor B adalah kawasan yang sudah produksi, namun hasil panen yang diperoleh belum mencapai kondisi optimal, dimana produktivitasnya hanya mencapai $2-3$ ton/Ha GKG dan masih di bawah target yang diharapkan yaitu 5 ton/Ha GKG. Keberadaan rice estate tampaknya belum merubah hasil produksi yang diinginkan jika pengelolaan manajemennya tidak maksimal, pada awalnya secara kelembagaan manajemen pengelolaan rice estate berada pada Dinas Pertanian dan Peternakan Kabupaten Kubu Raya. Seiring dengan perkembangan dan guna pemberdayaan Kelompok Tani yang ada, sejak januari 2012 pengelolaan manajemen diserahkan kepada kelompok tani, dari hasil wawancara dan penyebaran kuesioner perkembangan kawasan rice estate belum menunjukan hasil yang diharapkan masih ada beberapa lokasi lahan pertumbuhan padinya belum maksimal bahkan ada lahan yang menyemak kembali dengan produksi masih dibawah rata-rata (kurang dari $3000 \mathrm{~kg} / \mathrm{ha}$ ). Salah satu penyebab diantaranya masih lemahnya SDM petani maupun pengelola dilapangan. Terutama dalam menerapkan sistem manajemen usahatani dan cara pengelolaan kawasan, untuk itu perlu sekali pembinaan yang kontinyu dari instansi terkait agar peningkatan produksi dan pengelolaan kawasan dapat terlaksana sesuai yang diharapkant.

\section{Kualitas Beras Belum Sesuai Standar yang Diinginkan}

Rendahnya kualitas padi yang dihasilkann oleh petani di Kabupaten Kubu Raya khususnya di kawasan rice estate disebabkan antara lain rendahnnya sumber daya dan kesadaran petani terutama dalam penggunaan varietas, penerapan pupuk yang berimbang dan penanganan pasca panen. Para petani masih sulit merubah kebiasaan penggunaan benih varietas lokal menjadi varietas unggul, selanjutnya para petani masih kurang memperhatikan penanganan pasca panen terutama kegiatan grading pada saat panen. Hal ini terlihat dari produk yang bermutu dicampur dengan padi yang kualitasnya kurang baik, sehingga secara umum kualitas padi produknya menjadi rendah. Diperparah lagi sifat produk pertanian yang tidak merata baik bentuk, warna, rasa,dan ukurannya yang berpengaruh terhadap kualitas produk, sehingga belum sesuai dengan apa yang diinginkan konsumen. Varietas padi yang dibudidayakan petani dikawasan rice estate ada beberapa jenis diantaranya : Ciherang, Invara 2, Invara 3 Hiva 8 dan beberapa padi jenis lokal.

\section{d. Analisa Pembobotan dan Peratingan}

Selanjutnya dari proses mengidentifikasi faktor-faktor strategi internal yang meliputi kekuatan dan kelemahan, dilakukan analisis pembobotan dan peratingan. Hasil analisis matrik IFE pengembangan agribisnis padi melalui pembangunan rice estate di Kabupaten Kubu Raya yang menghasilkan faktor-faktor kekuatan dan kelemahan berdasarkan kuesioner dan wawancara (table 4). 
Tabel 4. Analisis Matriks IFE

\begin{tabular}{|c|c|c|c|c|}
\hline Faktor-faktor Strategis Internal & Bobot & Rating & Skor & Ranking \\
\hline \multicolumn{5}{|l|}{ Kekuatan } \\
\hline $\begin{array}{l}\text { 1. Kebijakan Pemerintah dalam mendukung } \\
\text { peningkatan produksi padi }\end{array}$ & 0,1474 & 4 & 0,5896 & 1 \\
\hline $\begin{array}{l}\text { 2. Kinerja pelayanan aparat terhadap masyarakat } \\
\text { tani }\end{array}$ & 0,1217 & 3 & 03651 & 1 \\
\hline 3. Adanya merek dagang & 0,1017 & 3 & 0,3051 & 3 \\
\hline $\begin{array}{l}\text { 4. Kemasan(ukuran) beras sesuai dengan } \\
\text { keinginan }\end{array}$ & 0,1011 & 3 & 0,3033 & 4 \\
\hline 5. Memiliki unit penggilingan padi & 0,0864 & 2 & 0,1728 & 5 \\
\hline Sub Total & 0,5583 & & 1,7359 & \\
\hline \multicolumn{5}{|l|}{ Kelemahan } \\
\hline 1. Parasaran dan sarana belum maksimal & 0,1085 & 3 & 0,3255 & 2 \\
\hline 2. Modal kerja belum mencukupi & 0,1159 & 3 & 0,3477 & 1 \\
\hline 3. Harga pokok produksi yang masih tinggi & 0,0733 & 2 & 0,1466 & 4 \\
\hline $\begin{array}{l}\text { 4. Sistem informasi manajemen ( SIM ) belum } \\
\text { diterapkan }\end{array}$ & 0,0862 & 2 & 0,1724 & 3 \\
\hline $\begin{array}{l}\text { 5. Kualitas beras belum sesuai standar yang } \\
\text { diinginkan }\end{array}$ & 0,0577 & 1 & 0,0577 & 5 \\
\hline Sub Total & 0,4416 & & 1,0499 & \\
\hline Total & 0,9999 & & 2,7858 & \\
\hline
\end{tabular}

Sumber : Hasil Pengolahan Data (2013)

Tabel 4. dapat dijelaskan, bahwa yang menjadi faktor utama kekuatan pengelolaan agribisnis padi dengan pola rice estate adalah Kebijakan Pemerintah dalam mendukung peningkatan produksi padi sawah, dengan skor 0,5896. Sedangkan yang menjadi faktor kelemahan adalah modal kerja, dengan skor 0,3477.

\section{e. $\quad$ Analisa Faktor - Faktor Eksternal Strategi Pengembangan Padi. \\ Faktor - factor Eksternal ( peluang )}

\section{e.1. Tersedianya lahan}

Luas Kabupaten Kubu Raya berdasarkan Undang Undang No. 35. Tahun 2007, $698.520 \mathrm{Ha}(65 \%)$ dari Kabupaten Induk, yaitu Kabupaten Pontianak. Bila dilihat dari Sub Sektor Pertanian Pangan terutama peruntukan untuk tanaman padi. Dari luasan lahan tersebut yang bisa diusahakan untuk tanaman padi $97.5 \%$, dengan rincian $178.781 \mathrm{Ha}$ (25.6\%) dengan kesesuaian lahan S.3 (sesuai bersyarat) dengan kendala drainase sangat 
terhambat, lahan tergenang dan lahan tergenang dengan pirit yang dalam dan $502.325 \mathrm{Ha}$ (71.9\%) dengan kesesuaian N.1 (tidak sesuai saat ini) dengan kendala ketebalan gambut dan air genangan. Lahan S.3 dan N.1 masih bisa ditingkatkan produktivitasnya dengan cara mengatasi kendala yang ada, seperti : optimasi pengelolaan lahan atau cetak sawah, terutama dalam hal pengaturan/ pembuatan saluran drainase dan ameliorasi lahan.

Pada tahun 2012 luas tanaman padi di Kabupaten Kubu Raya 63.440 Ha dengan luas panen 61.109 Ha. Ada sekitar 2.331 Ha gagal panen dikarenakan oleh adanya serangan hama dan penyakit tanaman, terutama hama tikus dan pengaruh dari perubahan (anomali) iklim, yaitu : musim panas / kekeringan. Rata-rata produksi tanaman padi $34.96 \mathrm{ton} / \mathrm{Ha}$ dengan total produksi 213.282 ton. Berdasarkan data-data di atas, maka lahan yang tersedia masih cukup luas. Dari total lahan yang tersedia dan bisa diusahakan untuk tanaman padi $681.106 \mathrm{Ha}$ (97.5\%) dari luas Kabupaten Kubu Raya, baru $63.440 \mathrm{Ha}(9.3 \%)$ yang digarap oleh petani, jadi masih ada seluas $617.666 \mathrm{Ha}(90.07 \%)$ sebelum dikurangi dengan peruntukan lahan lainnya.

\section{e.2. Teknologi Usaha Tani Padi}

Sejak awal tahun 1960 Pemerintah sudah membuat Program Peningkatan produksi padi melalui sistem Bimas dan Inmas, baik yang berupa perluasan areal tanam maupun peningkatan produksi per satuan luas yang dikenal dengan Sistem Panca Usaha Tani, yang meliputi : penggunaan benih unggul, pengairan/irigasi, bercocok tanam yang baik (tandur jajar), penggunaan saprodi pertanian dan pengendalian hama dan penyakit tanaman. Hingga sekarang Pemerintah tetap memprioritaskan program peningkatan produksi pertanian, terutama padi. Demikian juga di Kabupaten Kubu Raya, Teknologi Usaha Tani Padi sudah sejak dibukanya lahan pertanian oleh transmigasi sepontan dari Jawa Tengah tahun 1965, terutama di Kecamatan Sungai Kakap. Kemudian dilanjutkan di lahan-lahan penduduk transmigarasi di Desa Rasau Jaya Kecamatan Sungai Kakap (1971) yang sekarang sudah berubah menjadi Kecamatan Rasau Jaya. Sejak 1971 hingga sekarang Pemerintah Pusat melalui Kementerian Pertanian terus melanjutkan Pembanguan di Sektor Pertanian, terutama Sub Sektor Pertanian Tanaman Pangan, khususnya tanaman padi. Jadi tidak heran, jika Kabupaten Kubu Raya sekarang sudah berubah menjadi lumbung beras ke dua di Kalimantan Barat setelah Kabupaten Sambas, hal tersebut juga didukung oleh Program Kerja Bupati Kubu Raya Periode 2008-2013 “Beras Kubu Raya Beras Indonesia “.

\section{e.3. Permintaan Beras}

Kebutuhan akan beras di Indonesia tiap tahunnya meningkat, demikian juga di Kalimantan Barat termasuk di Kabupaten Kubu Raya. Hal ini disebabkan oleh beras merupakan makanan pokok $97 \%$ rakyat Indonesia, Di Indonesia mengkonsumsi beras tertinggi di Asia, yaitu : $102 \mathrm{Kg} / \mathrm{kavita} /$ tahun, sedangkan di Korea $40 \mathrm{Kg} / \mathrm{kavita} / \mathrm{tahun}$; Jepang $50 \mathrm{Kg} / \mathrm{kavita} / \mathrm{tahun}$, Malaysia $80 \mathrm{Kg} / \mathrm{kavita} /$ tahun dan Thailand $70 \mathrm{Kg} / \mathrm{kavita} / \mathrm{tahun}$. Indonsia pernah mankonsumsi beras $139 \mathrm{Kg} / \mathrm{kavita} / \mathrm{tahun}$ pada hal produksi beras dunia cuma 60 $\mathrm{Kg} / \mathrm{kavita} / \mathrm{tahun}$.

Produksi padi di Provinsi Kalimantan Barat 1.321.443 Kg GKG, bila dikonversi ke beras $63,2 \%$ maka akan didapatkan 768,321 ton beras, sedangkan konsumsi beras 591,26 ton beras. Permintaan akan beras dari tahun ke tahun semakin bertambah, hal ini disebabkan oleh pertambahan penduduk yang besar di Indonesia, termasuk di Kabupaten Kubu Raya. Selain itu disebabkan oleh rata-rata pertambahan penduduk di Indonesia masih termasuk tinggi, yaitu rata-rata : 1,49 \% / tahun atau setara dengan 3,5 juta jiwa per tahun. Sedangkan di Kalimantan Barat rata-rata pertambahan penduduk 0,91\%, dengan jumlah 
penduduk 4.052.345 jiwa di tahun 2005 menjadi 4.395.083 jiwa di tahun 2010. Di Kabupaten Kubu Raya pertumbuhan penduduk 1.57\% dengan jumlah penduduk 486.958 jiwa.

\section{e.4. Kebijakan Pemerintah Pusat dan Daerah yang Mendukung Pertanian Sawah.}

Pembuatan Undang-undang, Peraturan Pemerintah, Keputusan Presiden, Keputusan Menteri dan lain-lain dimaksudkan untuk mengamankan dan mendukung Kebijakan Pembangunan Pertanian, bertujuan untuk :

1). Memajukan pertanian

2). Mengusahakan agar pertanian jadi usaha produktif

3). Meningkatkan produksi dan efisiensi produksi

4). Tingkatkan pendapatan petani anggota

5). Tingkat kesejahteraan petani dan masyarakat meningkat.

Rumusan Kebijakan Pembangunan Pertanian untuk mendukung Sub Sektor Pertanian Tanaman Pangan dalam 4 tahun terakhir ini, berupa :

1) Kebijakan pengendalian konversi lahan sawah ke penggunaan non pertanian

2) Kebijakan reservasi lahan sawah di Jawa

3) Kebijakan kemandirian pangan nasional

4) Kebijakan penentuan harga dasar penjualan gabah

5) Kebijakan Tata Niaga dan distribusi pupuk bersubsidi di Indonesia

Di Kabupaten Kubu Raya dukungan Pemerintah terhadap Kebijakan Pembangunan Pertanian, seperti :

1. Terhadap petani, Kelompok Tani dan Gabungan Kelompok Tani

2. Terhadap penggilingan padi

3. Terhadap Koperasi

4. Terhadap Pegawai Negeri Sipil (PNS).

\section{e.5. Jumlah Penduduk Kubu Raya dan Kalimantan Barat yang Besar.}

Pertambahan penduduk di Indonesia masih termasuk tinggi, yaitu rata-rata : 1,49\%/ tahun atau setara dengan 3,5 juta jiwa per tahun. Sedangkan di Kalimantan Barat rata-rata pertambahan penduduk 0,91 \%, dengan jumlah penduduk 4,052.345 jiwa di tahun 2005 menjadi 4.395.083 jiwa di tahun 2010. Di Kabupaten Kubu Raya pertumbuhan penduduk $1.57 \%$ dengan jumlah penduduk 486.958 jiwa. Tingginya pertambahan penduduk di Kabupaten Kubu Raya disebabkan oleh belum berhasilnya Program Keluarga Berencana (KB). Program KB belum berhasil disebabkan oleh kurangnya tenaga kesehatan dan kurangnya dukungan terhadap peserta KB baru. Juga disebabkan oleh jarak yang jauh dan tidak menariknya tempat pelayanan.

\section{f. Faktor Ancaman untuk Pengembangan Agribisnis Padi.}

\section{F.1. Alih Fungsi Lahan Pertanian.}

Berdasarkan data dari Badan Pusat Statistik Indonesia, bahwa pada tahun 2010 terjadi 85.000 hektar lahan produktif untuk bidang pertanian dan pada tahun 2013 menjadi 130.000 hektar/tahun. Demikian juga di Kalimantan Barat, ternyata sejak tahun 2005 hingga sekarang 
produksi beras menurun sebesar 100.278.6 ton per tahun sebagai akibat dari beralihnya fungsi lahan pertanian tanaman pangan ke sektor perkebunan, pertambangan, HTI, HPH dan lain-lain. Hal ini terjadi disebabkan oleh RTRWP Kalimantan Barat belum akomudasi pertanian pangan berkelajutan. UU Penataan Ruang No. 26 Tahun 2007, masih menyisakan berbagai masalah krusial, seperti tarik menarik dalam kebijakan investasi yang didahulukan bila dibandingkan dengan perhatian terhadap kepentingan masyarakat.

\section{f.2. Serangan Organisme Pengganggu Tanaman dan Anomali Iklim}

Di Kabupaten Kubu Raya lahan didominasi oleh lahan rawa pasang surut. Pola tanam pada lahan pasang surut yang sering digunakan adalah polikultur. Keburukan pola tanam tersebut adalah, areal tanaman yang ditanami bukan padi menjadi sarang untuk berkembangnya hama dan penyakit tanaman, misalnya hama tikus, orong-orong, walang sangit, hama wereng, penyakit beluk/sundep, dan lain-lain. Tingginya serangan hama dan penyakit dapat berakibat menurunnya produksi per satuan luas. Hal lain yang juga menjadi ancaman adalah anomali (perubahan) iklim yang berakibat pada gagal panen yang disebabkan oleh kekeringan.

\section{f.3. Pasar Bebas}

Digulirkannya pasar bebas, maka ke berpihakan pemerintah kepada petani terasa makin berkurang, diperparah lagi dengan keputusan pemerintah yang setiap tahunnya melakukan impor beras. Walaupun pemerintah sudah menetapkan harga dasar beras, namun pada tingkat petani harga tersebut jarang tercapai. Ini disebabkan oleh adanya permainan harga oleh pedagang sebagai akibat dari adanya persaingan harga dengan beras impor yang relatif murah harganya. Petani baru terasa mendapat keuntungan apabila ada injeksi teknologi dan subsidi dari pemerintah dan bagi petani yang tidak mendapatkannya sudah barang tentu dari tahun ke tahun merugi. Akibatnya kesejahteraan yang diimpi-impikan oleh petani dan janji-janji yang pernah diucapkan oleh pemerintah untuk meningkatkan kesejahteraan petani belum terwujud secara maksimal.

\section{f.4. Tingkat Persaingan Penggilingan Padi.} diantaranya :

Dukungan Pemerintah Kabupaten Kubu Raya terhadap penggilingan padi

1) Sosialisasi dan advokasi sistem mutu beras kepada penggilingan

padi dan jaminan mutu beras kepada konsumen.

2) Dukungan pendanaan pelatihan, magang, studi banding

bagi penggilingan padi.

3) Kerjasama dengan organisasi profesi mulai perencanaan sampai implementasi.

4) Penyediaan skim kredit alsin penggilingan.

5) Bantuan Sarana Operasional berupa :

- Karung / kantung ukuran $10 \mathrm{Kg}$.

- Mesin jahit.

- Alat pengukur kadar air, dll. 
Jumlah penggilingan padi di Kabupaten Kubu Raya lebih kurang 274 Unit, sedangkan upah penggilingan padi berkisar antara Rp.150,- - Rp.200,-/ Kg. Banyaknya jumlah penggilingan padi ini berakibat pada tingginya persaingan usaha, terutama pada saat panen raya. Hal ini harus mendapat perhatian dan pembinaan terus menerus dari instansi terkait.

\section{f.5. Adanya Import - Eksport Beras llegal}

Eksport dan import beras ilegal di Kalimantan Barat sudah sangat lama terjadi. Di tahun 2001 saja 200 ton beras setiap hari diselundupkan ke Sarawak Malaysia Timur melalui Kecamatan Jagoi Babang Kabupaten Bengkayang. Sedangkan eksport beras ilegal terjadi di pelabuhan kecil yang ada di Pontianak dan pelabuhan kecil yang ada di Kalimantan Barat. Pada umumnya beras import ilegal ini akan di pasarkan di Jakarta. Dengan Masuknya beras import ilegal dari Thailand di Kalimantan Barat, sudah barang tentu akan merusak harga beras di pasaran dan yang paling dirugikan adalah para petani, karena harga gabah atau beras petani akan turun, sehingga penerimaan petani juga akan berkurang. Demikian juga jika terjadi eksport beras ilegal, petani tetap tidak merasakan pertambahan penerima, dikarenakan harga padi dan beras tidak pernah sampai pada harga dasar (floor price).

\section{g. Analisis matrik EFE}

Hasil analis matriks EFE pengembangan agribisnis padi melalui pola rice estate padi di Kabupaten Kubu Raya menghasilkan faktor peluang dan ancaman berdasarkan kuisioner dan wawancara (tabel 5), diperoleh dari perhotungan bobot dikalikan dengan rating didapatlah skor terbobot.

Bobot digunakan untuk mengetahui tingkat kepentingan relatif faktor penentu dalam pengembangan agribisnis padi melalui pola rice estate padi. Rating digunakan untuk menjelaskan respon Dinas Pertanian terhadap faktor-faktor penentu. Total skor terbobot untuk mengetahui kemampuan dalam memanfaatkan faktor peluang dan menyikapi faktor ancaman di luar lingkungan Dinas Pertanian dan Peternakan Kabupaten Kubu Raya.

Tabel. 5. Analisis Matrik EFE

\section{Faktor-faktor Strategis Internal Bobot Rating Skor Ranking}

\section{Peluang}

1. Tersedianya Lahan

2. Teknologi usaha tani padi

$\begin{array}{llll}0,1567 & 4 & 0,6268 & 1 \\ 0,0562 & 1 & 0,0562 & 5 \\ 0,1211 & 3 & 0,3633 & 2 \\ 0,1212 & 2 & 0,2424 & 3\end{array}$

4. Kebijakan Pemerintah Pusat dan Daerah yang mendukung pertanian sawah

5. Jumlah penduduk Kubu Raya dan Kalbar yang besar 


\section{Kelemahan}

1. Alih fungsi lahan pertanian

2. Serangan organisme penggangu tanaman

3. Pasar bebas

4. Tingkat Persaingan penggilingan padi yang tinggi

5. Adanya Import / eksport beras ilegal.

$\begin{array}{llll}0,1418 & 4 & 0,5952 & 1 \\ 0,1135 & 2 & 0,2270 & 2 \\ 0,0081 & 2 & 0,1620 & 3 \\ 0,0642 & 1 & 0,0642 & 4 \\ 0,0735 & 2 & 0,1470 & 4\end{array}$

1,1754

2,5286

Sumber : Hasil Pengolahan Data (2013)

Berdasarkan hasil analisis faktor eksternal diperoleh total skor terbobot 2,5286 karena berada di atas rata-rata $(2,500)$ hal tersebut berarti bahwa strategi secara efektif telah mampu kuat memanfaatkan peluang dan meminimalkan ancaman dalam pengembangan rice estate padi di Kabupaten Kubu Raya.

Tabel 5. mengungkapkan bahwa peluang utama yang dimiliki daerah Kabupaten Kubu Raya dalam mengembangkan agribisnis padi dengan pola rice estate adalah tersedianya lahan dengan skor 0,6268. Tingginya skor, karena pada umumnya untuk pengembangan dan pengelolaan rice estate padi masih sangat tergantung pada ketersediaan lahan. Ancaman utama dalam pengembangan rice estate untuk agribisnis padi adalah alih fungsi lahan pertanian dengan skor 0,5952. Faktor ancaman ini disebabkan oleh belum adanya ketegasan dari Pemerintah Daerah tentang Tata Guna Lahan atau Tata Ruang untuk Sektor Pertanian Tanaman Pangan, akibatnya sering terjadi tumpang tindih peruntukan lahan. Terutama dengan Sub Sektor Perkebunan, untuk perluasan Perkebunan Kelapa Sawit yang dikelola dalam bentuk PT atau CV oleh Perkebunan Pemerintah maupun Perkebunan Swasta.

Hasil analisis menunjukan, bahwa strategi pengembangan agribisnis padi melalui pembangunan rice estate di Kabupaten Kubu Raya dapat memanfaatkan peluang yang ada dengan memaksimalkan kekuatan yang dimiliki dengan jumlah skor rata-rata 3,2748 diatas nilai rata-rata 2,500 Strategi yang diusulkan kepada Pemerintah Kabupaten Kubu Raya dalam menentukan strategi pengembangan agribisnis padi melalui rice estate adalah dengan mendukung kebijakan pertumbuhan yang menggunakan strategi SO (StrengthOpportunities) . Strategi ini dibuat berdasarkan analisis strategi tentang pengembangan agribisnis padi melalui pola rice estate di Kabupaten Kubu Raya, yaitu berdasarkan lingkungan internal dan eksternal. Jadi Pemerintah Daerah Kabupaten Kubu Raya dapat memanfaatkan kekuatan yang terdiri dari :

1. Kebijakan Pemerintah dalam mendukung peningkatan produksi padi sawah.

2. Kinerja pelayanan aparat terhadap masyarakat tani.

3. Adanya merek dagang.

4. Kemasan(ukuran) beras sesuai dengan keinginan (segmen) konsumen. 
5. Memiliki unit penggilingan padi.

Juga merebut peluang, yang terdiri dari:

1. Tersedianya lahan.

2. Teknologi usaha tani padi.

3. Permintaan beras.

4. Kebijakan Pemerintah Pusat dan Daerah yang mendukung pertanian sawah.

5. Jumlah penduduk Kabupaten Kubu Raya dan Provinsi Kalimantan Barat yang besar.

\section{Alternatif Strategi Pengembangan Rice Estate Padi di Kabupaten Kubu Raya.}

Setelah melakukan analisis IFE dan EFE, kemudian faktor-faktor yang diperoleh dari masing-masing analisis tersebut dimasukan ke dalam matriks SWOT untuk dikombinasikan (matching stage). Penggunaan matriks tersebut bertujuan untuk merumuskan alternatif strategi dengan memadukan peluang dan ancaman yang kemungkinan dihadapi, dengan kekuatan dan kelemahan yang dimiliki dalam pengembangan agribisnis padi melalui pola rice estate padi di Kabupaten Kubu Raya. Akhirnya diperoleh strategi alternatif melalui strategi SO (Strenght-Opportunities), strategi W-O (Weaknesses-Opprtunities), strategi S-T (StrengthThreats) dan stategi W-T (Weaknesses-Threats). Alternatif strategi yang dihasilkan dari hasil matriks SWOT (tabel 6.) 
Tabel 6. Analisis SWOT Penentuan Alternatif Strategi

\section{FAKTOR INTERNAL}

\section{FAKTOR EKSTERNAL}

\section{Peluang (0)}

1.Tersedianya lahan

2.Teknologi usaha tani Padi

3.Permintaan beras

4.Kebijakan Pemerintah Pusat dan Daerah yang mendukung pertanian sawah

5.Jumlah penduduk Kab. Kubu Raya dan Prov. Kalbar yang besar.

\section{Kekuatan (S)}

1. Kebijakan Pemerintah dalam mendukung peningkatan produksi padi

2. Kinerja pelayanan aparat terhadap masyarakat tani

3. Adanye merek dagang

4. Kemasan (ukuran) beras sesuai dengan keinginan (segmen) konsumen.

6. Memiliki unit penggilingan padi.

\section{Strategi (SO)}

1.Peningkatan luas areal tanam dan peningkatan produksi dengan system agribisnis ( $\mathrm{S} 1, \mathrm{~S} 2, \mathrm{~S} 5$, $\mathrm{O} 1, \mathrm{O} 2, \mathrm{O} 4, \mathrm{O} 5$ )

2.Peningkatan Kualitas dan Kuantitas SDM aparat dan petani ( S1, S2, O4, O5 )

3.Peningkatan dan perbaikan pro- duk.( $\mathrm{S} 1$, S2, S3, S4, O4, O5)

\section{Ancaman (T)}

1.Alih fungsi lahan pertanian

2.Serangan organisme pengganggu tanaman

3.Pasar Bebas

4. Tingkat persaingan penggilingan padi yang tinggi

5.Adanya import/eksport Beras ilegal

1.Peningkatan inovasi teknologi untuk peningkatan provitas dan produksi ( $\mathrm{S} 1, \mathrm{~S} 2, \mathrm{~T} 1, \mathrm{~T} 2$, T3, T5 )

3.Perbaikan mutu dan kemasan produk ( S3, S4, S5, T3, T4, T5 )

\section{Kelemahan (W)}

1. Prasarana dan sarana belum maksimal

2. Modal kerja belum mencukupi

3. Harga pokok produksi yang masih tinggi

4. Sistem Informasi Manajemen (SIM) belum diterapkan

5. Kualitas beras belum sesuai standar yang diinginkan.

\section{Strategi (WO)}

1.Memanfaatkan SDA semaksimal mungkin secara arif dan berkelanjutan ( W2, W3, $\mathrm{O} 1, \mathrm{O} 2, \mathrm{O} 3, \mathrm{O} 4$ )

2.Menciptakan pasar lokal untuk produk lokal (W2, W3, W4, O2, O3, O5 )

\section{Strategi (WT)}

1.Memanfaatkan sarana prasana yang ada dengan maksimal (W1, W2, T1, T2, T4 )

2.Perbaikan penggunaan varietas yang dominan dengan pasar ( W2, W3, W5, T2, T3, T4, T5 ) 
Tabel 6. terlihat bahwa dengan menggunakan matriks SWOT dapat dihasilkan beberapa alternatif strategi, yaitu strategi S-O (strength-Opportunities), strategi S-T (StrengthThreats), strategi W-O (Weaknesses-Opportunities) dan strategi W-T (Weaknesses- Threats) antara lain :

Strategi S-O (Kekuatan-Peluang), yaitu strategi dengan menggunakan kekuatan yang dimiliki Pemerintah Daerah / Dinas Pertanian dan Peternakan Kabupaten Kubu Raya untuk memanfaatkan peluang yang ada, yaitu :

\section{a. Peningkatan luas areal tanam dan peningkatan produksi dengan system agribisnis.}

Menggunakan kekuatan dalam organisasi untuk memanfaatkan peluang yang ada. Strategi ini adalah suatu strategi yang berupaya untuk meningkatkan luas areal tanam melalui pengembangan kawasan yang berbasis agribisnis dengan pola rice estate padi yang ada dalam skala besar guna peningkatan hasil produksi dengan mengacu pada potensi wilayah dan masyarakat Kabupaten Kubu Raya. Strategi ini harus dipandang sebagai suatu kesatuan sistem mulai dari input, proses dan output. Bentuk kegiatan dari dari strategi ini yaitu: wilayah yang mempunyai sumber daya alam dan sumber daya manusia yang potensial dan cocok untuk tanaman padi, dijadikan rice estate padi, sehingga upaya pengembangan menjadi terfokus dan akan berdampak positif bagi pendapatan masyarakat, penciptaan lapangan kerja baru dan pengembangan wilayah, pengembangan agribisnis padi melalui rice estate dapat berupa intensifikasi dan ekstensifikasi tanaman padi. membangun dan meningkatkan sarana dan prasarana pendukung. Keterkaitan dan sinkronisasi kegiatan mulai dari hulu sampai hilir dalam rangka pengembangan kawasan produksi sangat penting untuk mendukung pengembangan tersebut, juga harus ditunjang oleh data potensi daerah yang lengkap mengenai komoditas padi.

\section{b. Peningkatan Kualitas dan Kuantitas SDM Aparat dan petani}

Strategi pengembangan Sumber Daya Manusia (SDM) merupakan strategi yang dilakukan dengan memanfaatkan kekuatan yang ada untuk menggapai peluang dengan sebaik-baiknya, diantaranya melalui kegiatan : Pelatihan yang rutin baik formal maupun non formal, temu kontak tani dan penyuluh lapangan demplot dan sekolah lapang. Strategi ini dilakukan pada sumber daya manusia yang terlibat dalam pengembangan agribisnis padi melalui pola rice estate di Kabupaten Kubu Raya baik pada petani maupun pada aparat dinas. Strategi ini harus dilakukan secara terprogram dan teratur dengan demikian diharapkan kemampuan manajemen petani semakin baik sehingga akses petani ke lembaga pemberi kredit akan lebih mudah, hal ini akan dapat mengatasi masalah klasik yang dihadapi petani, yaitu keterbatasan modal. Hal utama dalam strategi pengembangan SDM adalah, bahwa pengembangan SDM harus dapat merubah pola fikir dan perilaku berusaha tani, dari petani sub sistem menjadi petani yang berorientasi pasar.

Sementara dari sisi SDM aparat, dengan strategi ini akan dapat meningkatkan kinerja kelembagaan, sehingga aparat akan dapat mengintensifkan pembinaan dan memberikan pelayanan kepada masyarakat petani, sehingga akan terjalin kerjasama yang harmonis antara dinas dan petani dalam upaya pengembangan agribisnis padi melalui pola rice estate di Kabupaten Kubu Raya.

Dengan telah terjalinnya kerjasama yang baik antara petani dengan Pemerintah Daerah melalui Dinas Pertanian dan Peternakan Kabupaten Kubu Raya, masalah peningkatan produksi pertanian khususnya padi menjadi hal yang mudah. 


\section{c. Peningkatan dan Perbaikan Produk}

Strategi peningkatan dan perbaikan produk dihasilkan dengan menggunakan kekuatan dan memanfaatkan peluang Pemerintah Daerah / Dinas Pertanian dan Peternakan Kabupaten Kubu Raya dan masyarakat / petani perlu mengantisifasi produk sejenis yang dihasilkan oleh pesaing dari daerah lain, fluktuasi harga serta kebijakan politik perdagangan bebas dalam era globalisasi saat ini. Untuk mampu bersaing dengan daerah lain dan meminimalkan fluktuasi harga yang diperoleh masyarakat / petani, Pemerintah Daerah dan masyarakat / petani harus mampu menghasilkan padi yang berdaya saing tinggi. Salah satu strategi bisnis yang perlu dilakukan Pemerintah Daerah dan masyarakat di samping unggul harga, unggul segmentasi pasar, unggul citra adalah strategi unggul kualitas,yaitu : Penggunaan varietas unggul yang digemari banyak konsumen. Penggunaan pupuk dan pestisida berimbang dan wajar, tekhnik budidaya tanaman padi yang benar. Penampilan produk yang baik, menarik dan nilai guna tinggi untuk mencapai tujuan yang diharapkan.

Selain itu peningkatan dan perbaikan produk, dimaksudkan, bahwa sistem pertanian yang dikelola dengan pola rice estate produksinya akan lebih tinggi bila dibandingkan dengan produksi padi yang ditanam secara sub sistem oleh petani. Hal ini disebabkan oleh adanya masukan teknik budidaya yang benar untuk tanaman padi.

\section{Penentuan Strategi Alternatif Pengembangan Agribisnis Padi.}

Hasil analisis matriks SWOT menunjukan faktor strategis internal -eksternal yang diperoleh diketahui bahwa nilai strategi SO adalah 3,2748 dan strategi WO adalah 2,5888, strategi ST dengan nilai 3,0448 strategi WT dengan nilai 2,3588. Berkenaan dengan hasil matrik SWOT diatas untuk penentuan Strategi pengembangan agribisnis padi melalui pola rice estate di Kabupaten Kubu Raya dapat menggunakan strategi SO atau strategi yang menggunakan kekuatan untuk memanfaatkan peluang. Meskipun strategi SO mendapat nilai tertinggi, namun tiga strategi lainnya dapat diterapkan oleh Pemerintah Daerah Kabupaten Kubu Raya dalam pengembangan agribisnis padi melalui pola rice estate dengan tetap memperhatikan kondisi eksternal dan internal organisasi yang dapat mendukung penerapan strategi di atas.

\section{Strategi Peningkatan Luas Areal Tanam dan Peningkatan Produksi dengan system Agribisnis.}

Strategi ini adalah suatu strategi yang berupaya untuk meningkatan luas areal tanam dengan mengembangkan potensi komoditas padi dalam skala besar guna peningkatan hasil produksi semaksimal mungkin dengan mengacu pada potensi wilayah dan masyarakat yang ada. Strategi ini harus dipandang sebagai satu kesatuan sistem mulai dari input, proses dan output. Bentuk kegiatan dari strategi ini yaitu wilayah yang mempunyai sumber daya alam dan sumber daya manusia yang potensial dan cocok untuk tanaman padi dijadikan kawasan rice estate padi, sehingga upaya pengembangan menjadi terfokus dan akan berdampak positif bagi pendapatan masyarakat, penciptaan lapangan kerja baru dan pengembangan wilayah. Peningkatan luas areal tanam padi dapat berupa kegiatan intensifikasi dan ekstensifikasi, membangun dan meningkatkan sarana prasarana pendukung. Keterkaitan dan sinkronisasi kegiatan mulai dari hulu sampai hilir dalam rangka pengembangan atau perluasan area tanam padi sangat penting, untuk mendukung pengembangan tersebut juga harus ditunjang oleh data potensi daerah yang lengkap mengenai komoditas padi.

Adapun strategi yang dapat dijalankan untuk peningkatan luas areal tanam melalui pengembangan kawasan rice estate padi, diantaranya: 


\section{8.a. Peningkatan Kesejahteraan Petani.}

Untuk mewujudkan tujuan peningkatan kesejahteraan petani, terutama di sektor pertanian, maka perlu dipersiapkan kebijakan strategis untuk memperbesar atau mempercepat pertumbuhan sektor pertanian, khususnya peningkatan pendapatan dan kesejahteraan masyarakat. Salah satu cara untuk mencapai tujuan tersebut adalah pengembangan rice estate yang terencana dengan baik dan terkait dengan pembangunan sektor ekonomi lainnya.

Dalam mengatasi krisis ekonomi sekarang kebijakan ekonomi harus menganut pradigma baru dimana pemberdayaan ekonomi rakyat harus menjadi perhatian utama. Disebabkan oleh sebagian besar rakyat hidup pada sektor pertanian dan sektor ini masih memberikan kontribusi yang besar pada perekonomian negara, maka pemberdayaan ekonomi rakyat juga berarti membangun ekonomi pertanian lebih baik. Namun sebagian masyarakat yang tidak terlibat dalam kegiatan rice estate padi kehidupannya sangat memprihatinkan, karena keterbatasan sumber daya yang mereka miliki, antara lain modal, tingkat pendidikan dan keterbatasan pengetahuan mereka terhadap pemasaran produk pertanian. Dari sisi lain juga masih banyaknya daerah terisolir dan terbatasnya sarana transportasi. Hal ini menyebabkan sulitnya masyarakat petani untuk memasarkan produk mereka ke luar daerah. Guna mengatasi masalah yang dihadapi oleh masyakat pedesaan tersebut, maka perlu ditemukan suatu alternatif / strategi pemecahan masalah yang dihadapi oleh petani pedesaan. Dengan cara ini akan dapat membuka daerah pemasaran produk pertanian, sehingga dapat meningkatkan pendapatan masyarakat petani pedesaan. Strategi yang dimaksud :

- Membangun sarana infrastruktur jalan usaha tani / jalan produksi

- Mengadakan kredit usaha tani atau kredit ketahanan pangan kepada petani.

- Penguatan modal bagi petani melalui bantuan saprodi.

- Pengembangan dan pembangunan pasar tani dan pemberian bibit unggul.

- Pembinaan dan pengembangan sentra produksi.

\section{8.b. Peningkatan Sarana Prasarana dan Perbaikan Infrastruktur oleh Pemerintah Daerah.}

Pogram pembangunan rice estate (pola kerjasama kemitraan tripartite antara Pemerintah, Swasta dan petani) didukung dari beberapa aspek, yaitu : rehabilitasi dan pengembangan lahan, alat mesin pertanian,, tata guna air, pupuk dan pestisida, permodalan dan investasi. Rice estate dibangun secara berkelanjutan, yaitu dengan menjaga keseimbangan ekosistem alam, stabilitas harga serta menjamin keberlangsungan pengusahaan sistem komoditas padi secara efisien dan menghasilkan produk yang bermutu tinggi. Dengan adanya dukungan dari Pemerintah Daerah Kabupaten Kubu Raya melalui Dinas Pertanian dan Peternakan, diharapkan permasalahan sarana prasarana dan infrtruktur yang dihadapi oleh petani / poktan / gapoktan sudah teratasi dan produksi padi yang tinggi dan bermutu tinggi akan tercapai.

Aspek dasar dari pengembangan sarana dan prasarana (infrastruktur fisik seperti jalan, bendungan dan irigasi) dan sarana prasarana pendukung kegiatan produksi dan/atau pengolahan. Keberadaan infrastruktur sangat penting untuk menjamin akses keluar masuk transportasi ke kawasan, sehingga produk dapat tersalurkan ke luar kawasan dengan baik. Aspek sarana dan prasarana sangat penting dan menentukan kualitas produk yang 
dihasilkan. Meningkatnya pelayanan dan penyediaan sarana dan prasarana pengembangan rice estate seperti:

- Penyediaan infrastruktur fisik ( jalan, bendungan, irigasi dan sarana penyuluhan).

- Penyediaan sarana produksi dan budidaya.

- Pemasaran dan pengolahan hasil.

Strategi ini diharapkan dapat dilaksanakan dalam rangka untuk perbaikan dan peningkatan produksi ke arah yang lebih baik lagi.

\section{8.c. Penyuluhan dan Pendampingan Petani}

Penyuluhan dan pendampingan harus selalu berkoordinasi antara Kelompok Tani/Gapoktan dan Penyuluh Pertanian agar sasaran pelaksanaan antar Kelompok Tani/Gapoktan dan Penyuluh Pertanian tetap terjaga dengan baik dan tepat sasaran dari pokok-pokok kegiatan.

Petani merupakan pelaku utama usaha pertanian dalam pembangunan pertanian, sehingga perlu adanya kegiatan yang bertujuan menambah ilmu pengetahuan/SDM, para petani agar mampu menerapkannya dengan baik seiring perkembangan laju teknologi sekarang ini, oleh karena itu melalui Badan Pelaksana Penyuluhan Kabupaten Kubu Raya terus berupaya memberikan masukan baik itu berupa dukungan moral maupun material kepada petani dalam peningkatan SDM petani di daerah diantaranya :

- Pelatihan pengembangan diri.

- $\quad$ Sekolah Lapang Pengelolaann Tanaman Terpadu (SL-PTT).

- Bimtek, dll.

\section{8,d. Peningkatan Kemampuan Lembaga Petani}

Peningkatan kemampuan dan kualitas lembaga petani dapat ditingkatkan dengan salah satunya:

- Pembangunan gedung/saung untuk Kelompok Tani/Gapoktan, dimaksudkan agar kapasitas dan kualitas petani dalam berorganisasi dapat terfasilitasi dengan baik, tidaklah rapat-rapat koordinasi atau pertemuan antar Poktan/Gapoktan dilaksanakan di warung atau rumah warga.

- $\quad$ Pembangunan Gedung BPP, sebagai upaya pendekatann informasi berjenjang antara petani dan petugas pertanian.

- $\quad$ Adanya sarjana-sarjana pendamping desa sebagai motor pendamping masyarakat tani.

Hal diatas bertujuan untuk peningkatan kemampuan lembaga petani, dengan meningkatkannya pengetahuan, keterampilan dan sikap kelembagaan petani terhadap berbagai inovasi pertanian diharapkan akan terjadi perubahan yang besar terutama peningkatan produksi yang hasil akhirnya terjadi peningkatan pendapatan dan kesejahteraan masyarakat petani. Kelembagaan dan pelayanan penyuluhan yang lebih kuat akan meningkatkan $R$ \& $D$ pertanian yang berorientasi pada kebutuhan klien dan pasar serta membantu terwujudnya proses alih pengetahuan yang efektif kepada para petani lokal.

Upaya yang harus dilakukan petani untuk menaikkan posisi kelembagaan petani adalah dengan konsolidasi petani dalam suatu wadah kelembagaan untuk menyatukan gerak ekonomi dalam setiap rantai pertanian dari pra produksi sampai pemasaran, kolektifikasi 
produksi, yaitu perencanaan produksi secara kolektif untuk menentukan pola, jenis, kuantitas dan produksi secara kolektif dan kolektifikasi dalam pemasaran produk pertanian.

Prinsip dasar yang harus dipenuhi dalam pengembangan kelembagaan di pedesaan agar dapat berjalan dengan baik dan berkelanjutan adalah : prinsip otonomi (spesifik lokal), prinsip pemberdayaan petani dan prinsip kemandirian lokal.

\section{8,e. Peningkatan Sumber Daya Manusia (SDM).}

\section{a. Peningkatan Pengetahuan dan Keterampilan Petugas dan Petani / Poktan / Gapoktan.}

Peningkatan pengetahuan dan keterampilan yang diberikan kepada kelompok sasaran penyuluh, petani/Poktan/Gapoktan bertujuan untuk pengembangan pemikiran dan kreatifitas dalam rangka peningkatan hasil pertanian komoditas padi di rice estate, agar dapat meningkatkan kesejahteraan petani. Contohnya :

- Pelatihan pengolahan hasil komoditas padi (pasca panen dan penggilingan padi).

- Pelatihan Pemberdayaan Petani.

- Pelatihan Petugas Pertanian atau Penyuluh.

- Pelatihan Petani Pengelola dan Seleksi Varietas Padi (mutu beras).

\section{b. Peningkatan Penerapan Teknologi Pertanian}

Sejalan dengan pergeseran sistem dan manajemen produksi di masa yang akan datang dan menyikapi perkembangan permintaan pasar yang menyangkut mutu harga dan pelayanan, maka memerlukan strategi yang menghasilkan inovasi teknologi. Rendahnya produktivitas pangan yang cenderung melamdai serta kualitas (mutu) produk pertanian yang kurang dapat perhatian merupakan akibat langsung dari rendahnya tingkat inovasi teknologi yang diterapkan petani. Untuk itu diperlukan peningkatan penerapan teknologi yang mendukung peningkatan produktivitas dan mutu hasil. Program ini bertujuan untuk meningkatkan penerapan teknologi pertanian, meningkatnya produktivitas dan mutu hasil. Program tersebut dapat menghasilkan kegiatan pokok meliputi :

- Penerapan teknologi spesifik lokasi.

- Pengkajian teknologi pertanian.

- Pengembangan magang sekolah lapang.

- Peningkatan dan penyelenggaraan pelatihan pertanian.

- pengadaan sarana dan prasarana teknologi.

- pelatihan penerapan teknologi,demonstrasi dengan pola pendekatan penerapan teknologi tepat guna.

Berkaitan dengan upaya percepatan adopsi inovasi teknologi dan peningkatan kualitas SDM pertanian, maka kegiatan penyebaran teknologi dapat ditempuh melalui berbagai cara antara lain pelatihan teknologi pertanian petugas dan Kontak Tani di Kabupaten Kubu Raya. Tujuan pelatihan yaitu mempercepat penyebarluasan teknologi hasil penelitian dan pengkajian kepada pengguna (Petugas dan Kontak Tani) dalam rangka mendukung pengembangan usaha tani di pedesaan, meningkatkan pengetahuan, keterampilan dan sikap peserta (Petugas dan Kontak Tani) terhadap teknologi usaha tani yang dapat dikembangkan di wilayah pedesaan. Keluaran yang diharapkan, yaitu tersebarnya secara cepat teknologi hasil penelitian dan pengkajian kepada pengguna 
(Petugas dan Kontak Tani) dalam rangka mendukung pengembangan usaha tani di pedesaan, meningkatnya pengetahuan, keterampilan dan sikap Petugas dan Kompak Tani dalam penerapan Teknologi Pertanian yang lebih menguntungkan di pedesaan dan meningkatnya minat dan keyakinan dan Kontak Tani dalam penerapan teknologi

\section{8.d. Peningkatan dan Perbaikan Produk}

\section{a. Pengembangan Intensifikasi dan Ekstensifikasi Tanaman Padi}

Pengembangan intensifikasi dan ekstensifikasi usaha tani melalui pengembangan usaha tani dengan komoditas bernilai tinggi dan mengembangkan kegiatan off-farm untuk meningkatkan pendapatan dan nilai tambah melalui kegiatan pokok peningkatan kualitas pertumbuhan produksi padi. Intensifikasi dimaksudkan, suatu usaha peningkatan produksi padi per satuan luas, yaitu dengan mengintensifkan teknik budidaya padi agar didapat produksi yang optimal. Sedangkan ekstensifikasi adalah peningkatan produksi padi dengan cara perluasan areal tanam. Agar tetap didapatkan produksi padi yang tinggi sebaiknya keduanya dilakukan diversifikasi (penggabungan).

\section{b. Seleksi Varietas yang Akan Ditanam dan Optimalisasi Mutu \\ Penggilingan Padi.}

Agar mutu beras tetap terjamin, maka diperlukan kemampuan petani untuk mencari varietas padi yang paling diminati oleh konsumen. Oleh sebab itu peran dari tenaga Penyuluh Pertanian sangat diperlukan agar keterampilan pemilihan dapat dilakukan oleh petani, adapun varietas yang dominan di lapangan yang banyak diminati konsumen seperti : Ciherang, IR-64, Invara 2, Jenis Hibrida ( Pioneer dan Crown)

Hal lain yang tidak kalah pentingnya adalah mutu beras di penggilingan padi. Mutu beras diawali oleh prosentase rendeman yang standar, yaitu 65\% dengan beras patah tidak kurang dari $5 \%$. Selain itu mutu beras juga ditentukan oleh warna, kualitas rasa dan tekstur beras. Jika mutu beras sudah bisa dijamin oleh penggilingan padi, bukan tidak mungkin beras Kabupaten Kubu Raya benar-benar menjadi beras Indonesia.

\section{KESIMPULAN DAN SARAN}

\section{Kesimpulan}

Berdasarkan hasil analisis dan evaluasi strategi pengembangan rice estate di Kabupaten Kubu Raya yang telah diuraikan di atas dasar analisis lingkungan strategis, maka dapat disimpulkan sebagai berikut :

1. Faktor strategis internal berupa kekuatan yang bersifat penentu keberhasilan dalam pelaksanaan pengembangan rice estate padi oleh Pemerintah Kabupaten Kubu Raya adalah : Kebijakan Pemerintah dalam mendukung peningkatan produksi padi sawah, kinerja pelayanan aparat terhadap masyarakat tani, adanya merek dagang, kemasan (ukuran) beras sesuai keinginan (segmen) konsumen, memiliki unit penggilingan padi.

2. Faktor starategis internal kelemahan adalah : Prasarana dan sarana belum maksimal, modal kerja belum mencukupi, Harga pokok produksi yang masih tinggi, sistem Imformasi Manajemen (SIM) belum diterapkan kualitas beras belum sesuai standar yang diinginkan. 
3. Faktor strategi eksternal berupa peluang adalah : tersedianya lahan, teknologi usahatani padi, permintaan beras, kebijakan Pemerintah Pusat dan Daerah yang mendukung pertanian sawah, Jumlah penduduk Kabupaten Kubu Raya dan Provinsi Kalimantan Barat yang besar.

4. Faktor eksternal yang menjadi ancaman adalah : Alih fungsi lahan pertanian, Serangan organisme penggang serangan, Pasar bebas, Tingkat persaingan padi yang tinggi, Adanya import/eksport beras ilegal.

5. Dari hasil Analisis SWOT didapatkan hasil untuk strategi SO : 3,3748, strategi ST : 3,0488 , strategi WO : 2,5888 dan strategi WT : 2,3588. Dengan demikian strategi SO (Kekuatan-Peluang) yang terpilih diantara strategi lainnya karena jumlah skor lebih tinggi dan diatas rata-rata 2,500 .

6. Strategi pengembangan agribisnis padi melalui pola rice estate di Kabupaten Kubu Raya, yaitu : Pengembangan kawasan yang berbasis Agribisnis, dengan kegiatan : pemberdayaan ekonomi masyarakat tani, peningkatan sarana dan prasarana dan perbaikan infrastruktur oleh Pemerintah Daerah, penyuluhan dan pendampingan petani dan peningkatan kemampuan lembaga pertanian. Peningkatan SDM dan produksi, dengan kegiatan : peningkatan pengetahuan dan keterampilan Penyuluh Pertanian, petani/Poktan/ Gapoktan dan penerapan Teknologi Pertanian. Peningkatan dan perbaikan produk, dengan kegiatan : Pengembangan intensifikasi dan ekstensifikasi dan seleksi varietas yang akan ditanam dan optimalisasi mutu penggilingan padi.

\section{Saran}

Dalam merumuskan kebijakan pembangunan yang berorientase pada rice estate sebaiknya Pemerintah Daerah Kabupaten Kubu Raya mengacu pada pengembangan sub sektor tanaman pangan dengan komoditas padi. Hasil analisis lingkungan strategi yang telah dilakukan, posisi dan strategi pengembangan rice estate padi menggunakan strategi SO. Ini menunjukkan strategi yang diterapkan selama ini relatif cukup baik, tetapi masih dapat ditingkatkan agar lebih optimal dan memiliki daya saing yang kompetitif.

Selain itu hal-hal yang dapat disarankan adalah sebagai berikut : Optimalkan lahan rice estate yang sudah ditetapkan luasnya, agar menghasilkan produk yang bermutu dan berorientasi pasar

1. Diperlukan pengembangan infrastruktur pendukung baik untuk lahan maupun infrastruktur umum seperti jalan, jembatan, dll yang memadai disamping itu juga diperlukan petugas yang kontinyu dalam memberikan metode penyuluhan pertanian guna untuk memperbanyak introduksi informasi usaha agribisnis pertanian.

2. Diperlukan benih unggul lokal yang sudah banyak dibudidayakan dalam pengembangan rice estate padi dalam rangka memperkokoh dan mempertahankan ketahanan pangan dengan mempunyai ciri khas tersendiri produksi beras dari Kabupaten Kubu Raya

3. Perlu melakukan pembenahan pada beberapa faktor pembangunan dan rehabilitasi prasarana dasar untuk peningkatan produksi berupa cetak sawah, saluran drainase, tata air mikro dan jalan usaha petani.

Untuk mencapai keberhasilan pengembangan komoditas unggulan terpilih, maka strategi utama yang direkomendasikan perlu dijabarkan dalam bentuk program dan kegiatan yang tepat oleh Instansi terkait dengan Pemerintah Daerah sebagai koordinatornya. 


\section{DAFTAR PUSTAKA}

Albarru, Kaslieyitno. 2010. Analisis Strategi Pengembangan Usaha Koperasi Bina Usaha Al Ihsan Kecamatan Leuwiliang Kabupaten Bogor. Skripsi. Departemen Agribisnis. Fakultas Ekonomi dan Manajemen Institut Pertanian Bogor. Bogor.

Andoko, Agus. 2002. Budidaya Padi Secara Organik. Penebar Swadaya. Jakarta.

Anonim. 1996. Undang-undang No. 7 tahun 1996 tentang Pangan.

Badan Pusat Statistik. 2012. Statistik Indonesia. Jakarta.

Baga L, Yanuar R, Karo-Karo F, Aziz K. 2009. Koperasi dan Kelembagaan Agribisnis. Departemen Agribisnis. Fakultas Ekonomi dan Manajemen, Institut Pertanian Bogor. Bogor

Daryanto, A. 2001. Peranan Sektor Pertanian Dalam Pemulihan Ekonomi. Agrimedia Volume 6 Nomor 3 Februari 2001. Jakarta.

Didu, MS. 2000. Mencari Format Baru Agroindustri Dalam Millenium III. Agrimedia Volume 6 Nomor I Maret 2000. Jakarta.

Daswilza, 2002. Penentuan Komoditas Unggulan Agribisnis dan Strategi Pengembangannya di Kabupaten Agam Propinsi Sumatra Barat. Tesis Program Pasca Sarjarta. Institut Pertanian Bogor. Tidak dipublikasikan.

David. 2006. Manajemen Strategik. PT Prenhallindo. Jakarta

--------,.2009. Strategic Management : Manajemen Strategis Konsep. Edisi kedua belas. Salemba Empat. Jakarta.

Daniel, Moehar. 2002. Pengantar Ekonomi Pertanian. Bumi Aksara. Jakarta.

Dinas Pertanian dan Peternakan. 2009. Petunjuk Teknis Pengembangan Kawasan Agro Industri Padi (Rice Estate). Dinas Pertanian dan Peternakan Kabupaten Kubu Raya. Sungai Raya.

Djuwari. 1994. Aspek-aspek Ekonomi Usahatani. Program Pasca Sarjana. Universitas Gajah Mada. Yogyakarta.

Dumairy. 1996. Perekonomian Indonesia. Erlangga. Jakarta.

Edy Suprapto. 2010. Analisis Faktor-Faktor Yang Mempengaruhi Usahatani Padi Organik Di Kabupaten Sragen. Tesis. Universitas Sebelas Maret (UNS) Surakarta. Tidak Dipubikasikan.

Erwin. 2009. Analisis Strategi Pengembangan Usaha Koperasi Produk Susu (Studi Kasus Koperasi Produksi Susu dan Usaha Peternak Bogor, Jawa Barat. Skripsi. Program Studi Manajemen Agribisnis. Fakultas Petanian, Institut Pertanian Bogor. Bogor. Tidak Dipubikasikan.

FAO. 1992. FAOSTAT. (http://faostat.fao.org: diakses 15 Desember 2011)

Firdaus M. 2008. Manajemen Agribisnis. Penerbit Bumi Aksara. Jakarta

Fatriasari. W. 2004. Formulasi Strategi Pengembangan Komoditas Unggulan Agribisnis Di Kabupaten Trenggalek Propinsi Jawa Timur. Tesis Magister Manajemen Agribisnis. Institut Pertanian Bogor. Tidak dipublikasikan.

Hadi, P. U. dan Budi Wiryono. 2005. Dampak Kebijakan Proteksi terhadap Ekonomi Beras di 
Indonesia. Jurnal Agro Ekonomi. Vol.23 No.2, Oktober 2005. Pusat Penelitian dan Pengembangan Sosial Ekonomi Pertanian. Bogor.

Hax. A.C. and Majluf, N.S. 1996. The Strategy Concept And Process: A Pragmatic Approach $2^{\text {nd }}$. Printice Hall International, Inc. New Jersey.

Hernanto, Fadholi. 1993. IImu Usahatani. Penebar Swadana. Jakarta.

Hunger JD, Wheelen TL. 2003. Strategic Management 5th Edition. Penerjemah: Agung J. Yogyakarta: Andi.

Irawan, B. 2005. Konversi Lahan Sawah: Potensi Dampak, Pola Pemanfaatan dan Faktor Determinan. FAE. Vol.23 No.1. Juli 2005:1-18. Pusat

Penelitian dan Pengembangan Sosial Ekonomi Pertanian. Bogor.

Jacob, Juliani. 12008. Pembangunan Ekonomi Dalam Perspektif Islam. http://www.badkohmiaceh.blogspot.com. Diakses 9 Mei 2011.

Junarto, TA. 2008. Manajemen Strategi Pengembangan Koperasi Petani Organik Serikat Petani Indonesia di Bogor. Skripsi. Departemen Agribisnis. Fakultas Ekonomi dan Manajemen, Institut Pertanian Bogor. Bogor. Tidak Dipubikasikan.

Kamaluddin, Rustian. 1998. Pengantar Ekonomi Pembangunan. FEUI. Jakarta.

Kariyasa, K. 2003. Dampak Tarif Impor dan Kinerja Kebijakan Harga Dasar Serta Implikasinya Terhadp Daya Saing Beras Indonesia di Pasar Dunia. AKP. Vol.1 No.4, Desember 2003. Pusat Penelitian dan Pengembangan Sosial Ekonomi Pertanian. Bogor.

Khudori. 2008. Kaum Petani dan Paradoks Produktivitas Hasil Pertanian. http:/www.kompas.com. Diakses 29 Juni 2011.

Kotler P. 2003. Manajemen Pemasaran. PT Prenhallindo. Jakarta

-------,. 2007. Manajemen Pemasaran. Ed ke-12 Jilid 1 dan 2. Penerjemah: Molan B. PT Indeks. Jakarta.

Krisnamurthi, B. 2001. Agribisnis. Yayasan Pengembangan Sinar Tani. Jakarta.

Lakitan, Benyamin. Padi Hibrida : Apakah ini Jawabnya? http:/www.v.drn.go.id. Diakes 26 Mei 2011.

Mohd. Yusri. 2005. Analisis Faktor Produksi Padi Di Kabupaten Deli Serdang. Tesis. Universitas Sumatera Utara. Medan. Tidak Dipublikasikan.

Natzir, M. 1988. Metode Penelitian. Ghalia Indonesia. Jakarta.

Pearce J. dan R.B. Robinson. 1997. Manajemen Strategik. Formulasi Implementasi dan Pengendallan. Alih Bahasa Indonesia Agus. Mauluna. MSM. Binarupa Aksara. Jakarta.

Purnomo H. S., dan Zulkieflimansyah. 1999. Manajemen Strategik. Sebuah Konsep Pengantar, Penerbit Fakultas Ekonomi Ul. Jakarta.

Ramadhan, DA. 2009. Analisis Strategi Pengembangan KUD (Koperasi Unit Desa) Giri Tani, Kecamatan Cisarua, Kabupaten Bogor, Jawa Barat. Skripsi. Departemen Agribisnis. Fakultas Ekonomi dan Manajemen Institut Pertanian Bogor. Bogor. Tidak Dipubikasikan. 
Rangkuti. F. 2001. Analisis SWOT : Teknik Membedah Kasus Bisnis. PT. Gramedia Pustaka Utama. Jakarta.

Reijntjes, Coen, Haverkort, Bertus. dan Bayer, Waters. 1999. Pertanian Masa Depan. Kanisius. Yogyakarta.

Singarimbun. Masri dan Effendi, Sofian. 1995. Metode Penelitian Survai. Lembaga Penelitian. Pendidikan dan Penerangan Ekonomi dan Sosial. Yogyakarta.

Soekartawi. 2006. Analisis Usahatani. Universitas Indonesia Press. Jakarta.

Soemartono. 1990. Bercocok Tanam Padi. Yasaguna. Jakarta.

Surakhmad. Winarno. 1994. Pengantar Penelitian IImiah. Tarsito. Bandung.

Suryana. Ahmad. 2002. Keragaan Perberasan Nasional. Dalam Pambudy et al. (Eds). Kebijakan Perberasan di Asia. Regional Meeting in Bangkok. October 2002. 2003. Kapita Selekta Evolusi Pemikiran Kebijakan Ketahanan Pangan. Fakultas Ekonomi UGM. Yogyakarta

Mardianto, S. 2003. Apa itu Ketahanan Pangan. www.suarapembaharuandaily.com. Diakses 21 Mei 2011. Penulis Kepala Litbang Badan Ketahanan Pangan, Deptan dan Peneliti PSE-KP.

Tim Puslit Kependudukan LIPI. 2005. Ketahanan Rumah Tangga, http://www.lipi.go.id. Diakses 21 Mei 20011.

Umar, H. 2001. Strategic Management in Action. Gramedia. Jakarta.

Winardi J. 2003. Teori Organisasi dan Pola Pengorganisasian. Raja Grafindo Persada. Jakarta. 